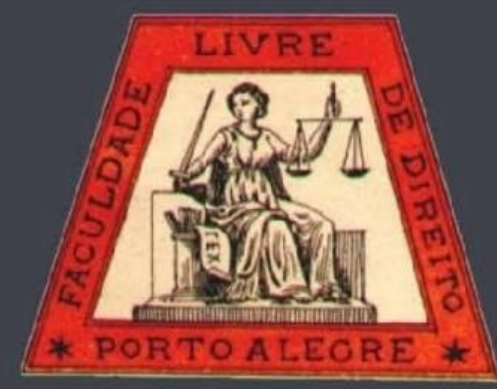

\title{
Fundamentos principiológicos para a proibição de publicidade dirigida à criança no Brasil
}

Principiological Fundamentals to the Prohibition of Child-Directed Advertising in Brazil

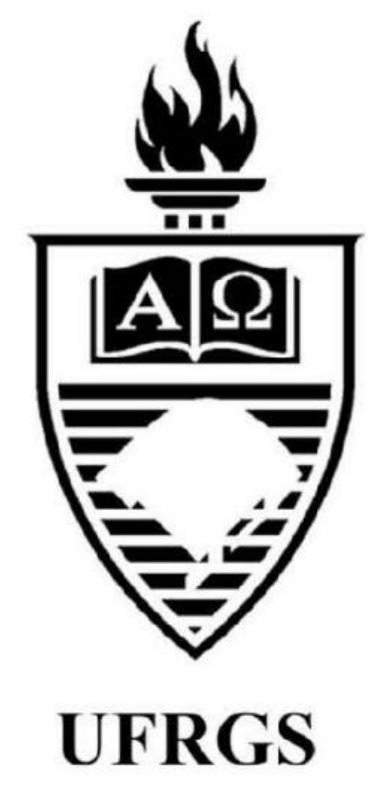

\author{
Fabiana D'Andrea Ramos \\ Universidade Federal do Rio Grande do Sul
}

Lisiane Zanatta

Universidade do Vale do Rio dos Sinos 


\title{
Fundamentos principiológicos para a proibição de publicidade dirigida à criança no Brasil
}

\author{
Principiological fundamentals to the prohibition of the children directed advertising in Brazil
}

Fabiana D'Andrea Ramos*

Lisiane Zanatta**

\section{REFERÊNCIA}

RAMOS, Fabiana D'Andrea; ZANATTA, Lisiane. Fundamentos principiológicos para a proibição da publicidade dirigida à criança no Brasil. Revista da Faculdade de Direito da UFRGS, Porto Alegre, n. 37, p. 183-199, dez. 2017.

\section{RESUMO}

O presente artigo apresenta, dentro do sistema normativo brasileiro, os fundamentos principiológicos que, para além das regras postas, sustentam a tese da abusividade da atividade publicitária dirigida às crianças. Descreve que a atividade publicitária é atividade econômica amparada pelo fundamento da livre iniciativa e, nessa condição, está sujeita ao regime constitucional e legal da ordem econômica. Nesse sentido, encontra limitação nos princípios que regem essa disciplina, tais como a dignidade da pessoa humana, a defesa do consumidor e a proteção integral da criança. Na órbita da proteção publicitária do consumidor, a proibição da publicidade dirigida à criança encontra amparo nos princípios da identificação e não abusividade, bem como no da hipervulnerabilidade do consumidor infantil.

\section{PALAVRAS-CHAVE}

Publicitária dirigida à criança. Defesa do consumidor. Vulnerabilidade do consumidor infant-juvenil. Publicidade abusiva.

\section{ABSTRACT}

The current article presents, within the Brazilian regulatory system, the logical fundaments that, beyond established rules, support the thesis of the unconscionability of the child-directed advertisement activity. It describes that adverstisement activity is an economic activity protected by the foundation of free initiative and, in this condition, is subjected to the constitutional and legal principles of the economic order. In this sense, it found restraints in the principles that govern this subject, such as human dignity, consumer protection and the full protection of children. On the scope of the consumer advertisement, the prohibition of childdirected advertisement finds its support in the principles of identification and non abusive adverstising, and also in the hyper vulnerability of the child consumer.

\section{KEYWORDS}

Child-Directed Advertising. Consumer Protection. Young Consumer Vulnerability. Abusive Advertising.

\section{SUMÁRIO}

Introdução. 1. Atividade Publicitária: Limites e Príncípio. 1.1. Liberdade de expressão e publicidade comercial. 1.2. Regime principiológico da atividade publicitária no Brasil. 2. Princípios que fundamentam a proibição da publicidade dirigida à criança. 2.1. Princípio da Identificação. 2.2. Princípio da não-abusividade. 2.3 Princípio da (hiper)vulnerabilidade ou vulnerabilidade agravada do público infanto-juvenil. 3. Considerações Finais. Referências.

\footnotetext{
* Professora Associada na Universidade Federal do Rio Grande do Sul. Doutorado em Direito pela Universidade do Estado do Rio de Janeiro (2005), graduação em Ciências Jurídicas e Sociais pela Universidade Federal do Rio Grande do Sul (1997), mestrado em Direito pela Universidade de Heidelberg (1998). Secretária Executiva da Rede Brasileira de Pesquisadores em Direito Internacional e $2^{\text {a }}$ Vice-Presidente do Instituto Brasileiro de Política e Direito do Consumidor.

** Graduação em Direito na Universidade do Vale do Rio dos Sinos, advogada.
} 


\section{INTRODUÇÃO}

Em recente julgado de $2016^{1}$, decidiu o Superior Tribunal de Justiça que a publicidade de alimentos dirigida direta ou indiretamente às crianças é abusiva, porque a decisão de compra e consumo de gêneros alimentícios deve residir com os pais e, ainda, porque, na forma do artigo 37, §2 ${ }^{\circ}$, do Código de Defesa do Consumidor, seria abusiva toda campanha publicitária que se utilize ou manipule o universo lúdico infantil.

A campanha em questão houvera sido veiculada em 2007 e consistia em uma "promoção", onde as crianças precisavam juntar cinco embalagens de qualquer produto de uma certa linha de biscoitos, para, pagando o valor de cinco reais, "ganhar" um relógio exclusivo de um personagem de filmes infantis. A $2^{\text {a }}$ Turma do Superior Tribunal de Justiça considerou que a ilegalidade também estava configurada em face da evidente venda casada promovida pela anunciante.

Também no ano de 2016, os coordenadores do Projeto Criança e Consumo, vinculado ao Instituto Alana ${ }^{2}$, representaram junto ao Ministério Público Federal contra 15 empresas que adotaram a prática da publicidade abusiva dirigida a crianças. A abusividade se

\footnotetext{
${ }^{1}$ PROCESSUAL CIVIL. DIREITO DO CONSUMIDOR. AÇÃO CIVIL PÚBLICA. VIOLAÇÃO DO ART. 535 DO CPC. FUNDAMENTAÇÃO DEFICIENTE. SÚMULA 284/STF. PUBLICIDADE DE ALIMENTOS DIRIGIDA À CRIANÇA. ABUSIVIDADE. VENDA CASADA CARACTERIZADA. ARTS. 37, $\S 2^{\circ}$, E 39, I, DO CÓDIGO DE DEFESA DO CONSUMIDOR.

1. Não prospera a alegada violação do art. 535 do Código de Processo Civil, uma vez que deficiente sua fundamentação. Assim, aplica-se ao caso, mutatis mutandis, o disposto na Súmula 284/STF.

2. A hipótese dos autos caracteriza publicidade duplamente abusiva. Primeiro, por se tratar de anúncio ou promoção de venda de alimentos direcionada, direta ou indiretamente, às crianças. Segundo, pela evidente "venda casada", ilícita em negócio jurídico entre adultos e, com maior razão, em contexto de marketing que utiliza ou manipula o universo lúdico infantil (art. 39, I, do CDC).

3. In casu, está configurada a venda casada, uma vez que, para adquirir/comprar o relógio, seria necessário que o
}

caracterizaria pelo ato de as empresas enviarem seus produtos a youtubers mirins, a fim de que esses gravem os respectivos vídeos demonstrando a sua utilização, fazendo com que a divulgação seja direcionada ao público específico gerando sentimento de necessidade do consumo de determinado bem.

Um dos fundamentos que sustenta tais entendimentos é a Resolução 163, do Conselho Nacional dos Direitos da Criança e do Adolescente (CONANDA), publicada em 13 de março de 2014, a qual considera abusiva a prática de publicidade e comunicação mercadológica dirigida à criança.

No entanto, é possível afirmar com segurança que a abusividade da publicidade dirigida às crianças está presente no ordenamento jurídico brasileiro desde a promulgação do Código de Proteção e Defesa do Consumidor, em 1990, encontrando sua gênese ainda antes disso, em 1988, na Constituição Federal.

A proposta do presente artigo é apresentar, dentro do sistema normativo brasileiro, os fundamentos principiológicos que, para além das regras postas, sustentam a tese da abusividade da atividade publicitária dirigida às crianças. Para tanto, serão abordados inicialmente os temas dos limites e dos princípios que regem a atividade

consumidor comprasse também 5 (cinco) produtos da linha "Gulosos".

Recurso especial improvido.

(REsp 1558086/SP, Rel. Ministro HUMBERTO MARTINS, SEGUNDA TURMA, julgado em 10/03/2016, DJe 15/04/2016)

2 "O Instituto Alana é uma organização sem fins lucrativos que trabalha para encontrar caminhos transformadores que honrem a criança. Para tanto, atua em um amplo espectro em busca de garantir condições para a vivência plena da infância, fase essencial na formação humana. São quatro frentes de atuação: Alana Comunidade, Alana Educação, Alana Defesa e Alana Futuro." (SILVA, Virgíliio Afonso da. A Constitucionalidade da Restrição da Publicidade de Alimentos e de Bebidas Não Alcoólicas voltada ao Público Infantil. <http://criancaeconsumo.org.br/wpcontent/uploads/2014/02/Parecer_Virgilio_Afonso_6_7_1 2.pdf> Acesso em: 22 jun. 2016.) 
publicitária. Nesse contexto será traçada a relação entre publicidade comercial e liberdade de expressão. Posteriormente, a partir da menção ao regime principiológico da publicidade no Brasil, serão abordados especificamente aqueles princípios que fundamentam a proibição da publicidade dirigida à criança.

\section{ATIVIDADE PUBLICITÁRIA: LIMITES E PRINCÍPIOS}

\subsection{Liberdade de expressão e publicidade comercial}

A atividade publicitária é muito frequentemente incluída dentro do regime de proteção da liberdade de expressão. Este entendimento pode bem ser atribuído à tradição constitucional norte-americana, que desenvolveu o conceito do commecial free speech. ${ }^{3} \mathrm{~A}$ diferença de contextos constitucionais, no entanto, não permite a importação incondicionada dessa jurisprudência estrangeira. ${ }^{4}$

\footnotetext{
${ }^{3}$ Sobre as origens e o conceito da liberdade de expressão ver PASQUALOTTO, Adalberto. Publicidade de tabaco e liberdade de expressão. Revista Direito do Consumidor. v. 82, abr.-jun.,2012, p. 11-28.

4 PASQUALOTTO, Adalberto (Org.). Publicidade de Tabaco: frente e verso da liberdade de expressão comercial. São Paulo: Atlas, 2015, Prefácio, p. XIII.

5 "Onipresente. Se há uma palavra que poderia definir a publicidade, onipresente talvez seja uma das principais, afinal, ela está nas ruas, na televisão, nos jornais, nas revistas, na internet, nos filmes, no rádio assim como em nossas correspondências, em ônibus e, quem sabe, em um saco de pão. No entanto, uma campanha publicitária só se concretiza a partir dos meios de comunicação de massa (o que aliás, lhe garante a onipresença). Própria da economia capitalista, contemporânea e parceira do jornalismo, o estudo da publicidade, além da comunicação implica a psicologia, comportamentos, valores, atitudes e, ainda, outras dimensões da vida social e da cultura." MARTINO, Luiz Cláudio. PAVARINO, Rosana Nantes. História e teoria da publicidade: origem e autonomia. Colección Académica de Ciencias Sociales da Universida Pontificia Bolivariana. Seccional Palmira. v. 2., n. 1. 2015. p. 01.

${ }^{6}$ Art. $1^{\text {o }}$ A República Federativa do Brasil, formada pela união indissolúvel dos Estados e Municípios e do Distrito
}

No Brasil, o exercício da atividade publicitária ${ }^{5}$ é assegurado pelas regras constitucionais, especialmente, princípios constitucionais informadores da ordem econômica, previstos nos art. $1 .^{\text {o } 6}$ e art. $170^{7}$ da Constituição Federal. Da simples leitura dos referidos dispositivos verifica-se que tal atividade econômica é protegida pelo princípio da livre concorrência e por um dos fundamentos da ordem econômica que é a livre iniciativa. Encontra também, proteção no inciso IX do art. 5. ${ }^{\circ}$, pelo princípio da liberdade de expressão. Contudo, há restrições ao conteúdo de tal atividade, consoante fundamento constitucional da dignidade da pessoa humana, prevista no inciso III do art. $1^{\circ}$, o direito e garantia fundamental da defesa do consumidor, no inciso XXXII do art. $5 .^{\circ}$ e os $\S \S$ $3^{\circ}$ e $4^{\circ}$ do art. 220 da Constituição Federal. Dessa forma, inúmeros doutrinadores alicerçam suas conclusões nas diferentes nuances previstas no ordenamento jurídico para defender tanto a inconstitucionalidade da restrição da publicidade destinada à criança ${ }^{8}$, quanto sua constitucionalidade.

Federal, constitui-se em Estado Democrático de Direito e tem como fundamentos: IV - os valores sociais do trabalho e da livre iniciativa.

${ }^{7}$ Art. 170. A ordem econômica, fundada na valorização do trabalho humano e na livre iniciativa, tem por fim assegurar a todos existência digna, conforme os ditames da justiça social, observados os seguintes princípios: [...] IV - livre concorrência; Parágrafo único. É assegurado a todos o livre exercício de qualquer atividade econômica, independentemente de autorização de órgãos públicos, salvo nos casos previstos em lei.

8 "Pensar a criança hoje não é apenas considerar sua faixa etária ou seu amadurecimento, tampouco é imaginá-la desconectada da sociedade — um "ser" à parte, alheio a tudo que o cerca. Pensar a criança hoje é considerá-la um ser social, plenamente integrado a seu meio, influenciando e sendo influenciada por ele.” RIMOLI, Ariane Porto Costa. O mundo da comunicação e o mundo da criança. Comunicação \& Educação. São Paulo, v. 21, n. 1, p. 51-59, may 2016. ISSN 2316-9125. Disponível em: <http://www.revistas.usp.br/comueduc/article/view/96724 >. Acesso em: 03 jul. 2016. doi:http://dx.doi.org/10.11606/issn.2316-9125.v21i1p5159. 
Um dos doutrinadores defensores da liberdade da atividade publicitária dirigida à criança é Nelson Nery Junior, segundo o qual, “a proibição, em abstrato, da realização da publicidade infantil caracteriza violação ao princípio da livre-iniciativa (CF 170), liberdade de expressão e do direito à informação (CF 220), e, caso feita por meio de decisão judicial, configura ainda violação ao princípio da legalidade (CF $5^{\circ}$ II) e da tripartição dos poderes." 9

Para Lucia Ancona, embora haja ampla proteção constitucional, tal atividade não é ilimitada. Aduz que:

\begin{abstract}
A própria $\mathrm{CF}$ cuidou também de prever restrições à veiculação publicitária, estabelecidas nos $\S \S 3^{\circ}$ e $4^{\circ}$ do art. $220^{10}$. O $\$ 3^{\circ}$ prescreve que compete à lei federal estabelecer novas restrições à publicidade de produtos ou serviços que possam ser nocivos à saúde e ao meio ambiente. $\mathrm{O} \S 4^{\circ}$, por sua vez, contém rol taxativo dos produtos potencialmente nocivos, isto é, cujo uso já se presume de efeitos nocivos [... $]^{11}$.
\end{abstract}

Virgílio Afonso da Silva, por sua vez, afirma que ainda que a atividade publicitária seja forma de expressão, ela pode ser restringida por medidas estatais. Nesse sentido, qualquer restrição à atividade publicitária, em especial, quanto a dirigida à criança, deverá ser analisada aplicando-se o princípio da proporcionalidade,

\footnotetext{
${ }^{9}$ JUNIOR, Nelson Nery. Limites para publicidade infantil: Direito fundamental à comunicação e liberdade de expressão da iniciativa privada. Soluções Práticas de Direito. Revista dos Tribunais. v. 1, 2014, p. 460.

${ }^{10}$ Art. 220. A manifestação do pensamento, a criação, a expressão e a informação, sob qualquer forma, processo ou veículo não sofrerão qualquer restrição, observado o disposto nesta Constituição. [...] $\S 3^{\circ}$ Compete à lei federal: I - regular as diversões e espetáculos públicos, cabendo ao Poder Público informar sobre a natureza deles, as faixas etárias a que não se recomendem, locais e horários em que sua apresentação se mostre inadequada; II - estabelecer os meios legais que garantam à pessoa e à família a possibilidade de se defenderem de programas ou programações de rádio e televisão que contrariem o disposto no art. 221 , bem como da propaganda de produtos, práticas e serviços que possam ser nocivos à saúde e ao meio ambiente. $\S 4^{\circ}$ A propaganda comercial de tabaco, bebidas
}

que "é o instrumento apto a impor limites à atividade restritiva infraconstitucional." Refere ainda o autor que "as restrições legais a algum direito previsto constitucionalmente serão consideradas como constitucionais se, além de respeitarem os requisitos de forma e competência, passarem no teste da proporcionalidade."12

Tais opiniões revelam que a possibilidade da imposição de limites ao exercício da atividade publicitária (que se pressupõe para fins comerciais), posto que prevista no próprio texto constitucional, bem como na legislação infraconstitucional $^{13}$, não é contestada. A dúvida versa sobre a extensão dessa limitação, mesmo a proibição em abstrato, como mencionado por Nelson Nery, a qual se poderia configurar como censura.

O equívoco parece residir em vincular a publicidade comercial ao regime da liberdade de expressão, equiparando tal atividade a outras formas de expressão intelectual, artística, científica ou de comunicação. Nesse sentido, é necessário acompanhar a precisão do pensamento de Bruno Miragem acerca do fundamento constitucional da atividade publicitária. Segundo o autor, "não se pode desconsiderar que a publicidade distingue-se de modo decisivo das demais formas de expressão, sobretudo pela vinculação íntima da atividade publicitária a um

alcoólicas, agrotóxicos, medicamentos e terapias estará sujeita a restrições legais, nos termos do inciso II do parágrafo anterior, e conterá, sempre que necessário, advertência sobre os malefícios decorrentes de seu uso.

${ }^{11}$ DIAS, Lucia Ancona Lopez de Magalhaes. Publicidade e hipervulneráveis: limitar, proibir ou regular?. Revista de Direito do Consumidor. v. 99, p. 288, mai-jun, 2015. DTR\2015 10681

12 SILVA, Virgílio Afonso da. A constitucionalidade da restrição da publicidade de alimentos e de bebidas não alcóolicas voltada ao público infantil (Parecer). São Paulo: Instituto Alana, 2012. Disponível em: $<$ http://criancaeconsumo.org.br/wp-

content/uploads/2014/02/Parecer_Virgilio_Afonso_6_7_1 2.pdf>. Acesso em: 26 jun. 2016. p. 20

${ }^{13}$ São exemplos as previsões de publicidade enganosa e abusiva, do artigo 37 do Código de Proteção e Defesa do Consumidor. 
fim eminentemente econômico"14. A publicidade comercial encontraria seu fundamento, pois, na livre iniciativa, prevista no $\operatorname{artigo} 1^{\circ}$, IV, da Constituição Federal, mais especificamente no âmbito da iniciativa econômica, a qual, conforme previsão constitucional, é condicionada (e, pois, limitada) aos princípios da função social da propriedade, livre concorrência, defesa do meio ambiente e defesa do consumidor. Conclui o autor que:

Colocar-se a publicidade, conceitualmente vinculada à finalidade eminentemente econômica, sob a égide da liberdade de expressão, de modo a limitar a possibilidade ou intensidade da sua restrição ou controle a partir de determinações estabelecidas na própria Constituição, e regradas pela legislação ordinária, é outorgar um privilégio que, além de não ser razoável, carece de fundamentação jurídica. Tais restrições à publicidade serão legítimas quando realizadas em consideração da promoção de direitos fundamentais de relevo, tais como a proteção do consumidor, da criança, ou da saúde pública, de modo a conformar a liberdade de iniciativa econômica, assento constitucional da atividade publicitária. $^{15}$

Uma vez devidamente identificado o marco constitucional que ampara a publicidade comercial e o consequente regime jurídico a que está submetida, é possível concluir que a atividade publicitária pode ser limitada diretamente pela lei, como faz o Código de Proteção e Defesa do Consumidor ao proibir a publicidade abusiva, bem como pela ponderação de princípios constitucionais, mormente aqueles que garantem direitos fundamentais, como é o caso da proteção integral à criança.

Como se verá mais adiante, a proibição da publicidade dirigida à criança não pode ser vista como uma limitação em abstrato, uma vez que não se proíbe a publicidade em si do produto ou serviço. A liberdade de expressão comercial, pois,

\footnotetext{
${ }^{14}$ MIRAGEM, Bruno. Curso de Direito do Consumidor. 5. ed. São Paulo: Editora Revista dos Tribunais, 2014, p. 250/251.

${ }^{15}$ Ibidem, p. 252.
}

está garantida. A proibição reside somente no destinatário da mensagem comercial, a criança, pois esse não é o sujeito econômico que tem condições cognitivas e emocionais de absorver a mensagem sem arriscar prejudicar seu próprio desenvolvimento. Referir-se a essa limitação como uma proibição em abstrato é em si mesmo enganoso, porque o que se considera é que a publicidade comercial dirigida ao público infantil é per se abusiva, na forma da previsão legal, independentemente do seu conteúdo. Tal conclusão encontra fundamento nos princípios que regem essa atividade no Brasil, como se verá a seguir.

\subsection{Regime principiológico da atividade publicitária no Brasil}

Considerada como meio de comunicação de massa, atualmente a publicidade tem como principal objetivo o de divulgar as novidades que o mercado de consumo produz, estimulando, de forma imediata e com mecanismos cada vez mais sofisticados, o desejo ao consumo de bens e serviços. ${ }^{16}$ Dessa maneira induz, de forma quase que inconsciente, o público-alvo a adquirir produtos ou serviços disponíveis no mercado de consumo, que, muitas vezes, não pretendia.

As técnicas de persuasão desenvolvidas pelos profissionais especializados na área de publicidade, utilizadas para convencimento do consumidor, estão cada dia mais complexas e sofisticadas. Isso porque, verifica-se o movimento dos profissionais da área de publicidade lançando mão de análises técnicas do funcionamento do cérebro humano para mapear o comportamento do consumidor, especialmente suas reações aos elementos e situações desenvolvidas nas peças publicitárias com nítido objetivo de estimular o

${ }^{16}$ Ainda em 1994, o autor argentino Luis Melnik afirmava: "La vida es el objetivo aparentemente más buscado por la publicidad". MELNIK, Luis. La Publicidad: princípios, médio y fines. Buenos Aires: Editorial Sudamericana, 1994, p. 13. 
consumo, muitas vezes, impensado de bens ou serviços. Daí porque faz-se necessária a especial proteção do consumidor infantil, sujeito ainda em desenvolvimento, com menor capacidade de discernimento, com deficiência de julgamento, ingenuidade, credulidade, inexperiência, entre outras características psicológicas.

Ressalta-se que, na esfera jurídica, o termo publicidade deve ser entendido como todas as formas de comunicação, também referidas na legislação como comunicação de caráter publicitário, comunicação mercadológica, comunicação publicitária, anúncios publicitários, propaganda comercial, tanto imediata como mediata também, conhecida como mensagem subliminar que, de forma sutil, incentiva um determinado comportamento no consumidor, em especial o infantil.

$\mathrm{O}$ art. $8^{\circ}$ do Código Brasileiro de Autorregulamentação Publicitária traz a definição de publicidade como sendo "atividades destinadas a estimular o consumo de bens e serviços, bem como promover instituições, conceitos ou ideias".

Lucia Ancona se refere a publicidade como sendo "o meio de divulgação de produtos e serviços com a finalidade de incentivar o seu consumo. Trata-se de duto par excellence através do qual se leva ao conhecimento dos consumidores em geral a existência de bens e serviços a serem examinados e eventualmente adquiridos". ${ }^{17}$

Em razão disso, a publicidade difere-se da propaganda, visto que esta tem como objetivo "a divulgação de qualquer ideia com o fito de fazer proselitismo político, social ou religioso". ${ }^{18}$ Isto é, a propaganda visa a divulgação de ideias de

\footnotetext{
${ }^{17}$ DIAS, Lucia Ancona Lopez de Magalhaes. Publicidade e direito. 2. ed. São Paulo: Revista dos Tribunais, 2013, p. 21. ${ }^{18}$ DENARI, Zelmo. A comunicação social perante do Código de Defesa do Consumidor. Revista de Direito do Consumidor. São Paulo, n. 4, p. 135.

19 MARQUES, Claudia Lima. Contratos no Código de Defesa do Consumidor: o novo regime das relações contratuais. 7. ed. São Paulo: Revista dos Tribunais, 2014. p. 872
}

natureza ideológica, filosófica, religiosa, política, moral, entre outras, diferentemente da publicidade, embora, muitas vezes, no meio jurídico, inclusive no texto legal, sejam utilizadas indevidamente como sinônimo.

Para Cláudia Lima Marques a definição de publicidade é "toda informação ou comunicação publicitária difundida com o fim direto ou indireto de promover junto aos consumidores a aquisição de um produto ou a utilização de um serviço, qualquer que seja o local ou meio de comunicação utilizado". ${ }^{19}$ E é exatamente através desse meio de divulgação de massa "que o fornecedor de bens ou serviços ao consumidor, que informa o consumidor sobre determinadas qualidades ou propriedades do produto ou serviço, que desperta interesses, vontades, desejos, que propaga marcas e nomes, que usa a fantasia para ligar determinados sentimentos, status ou atitudes a determinados produtos, em verdade, o fornecedor incita ao consumo, direta ou indiretamente, com sua atividade". ${ }^{20}$

Nessa linha, Bruno Miragem aduz que "a atividade publicitária é inerente ao mercado de consumo contemporâneo. Seus efeitos, aliás, ultrapassam uma perspectiva meramente econômica, influenciando na definição de comportamentos sociais" ${ }^{21}$.

Essa atividade, como já mencionado acima, deve ser compreendida como atividade econômica, inserida dentro do arcabouço constitucional e legal da ordem econômica e não necessariamente protegida pelas garantias destinadas à liberdade de expressão e pensamento. Nesse sentido, aplicam-se-lhe os princípios do artigo 170, da Constituição Federal,

\footnotetext{
${ }^{20}$ MARQUES, 2014, op. cit., p. 872.

${ }^{21}$ MIRAGEM, Bruno. Proteção da criança e do adolescente consumidores. Possibilidade de explicitação de critérios de interpretação do conceito legal de publicidade abusiva e prática abusiva em razão de ofensa a direitos da criança e do adolescente por resolução do Conselho Nacional da Criança e do Adolescente - CONANDA. PARECER. Revista de
} Direito do Consumidor. v. 95, p. 460, set-out, 2014. 
dentre os quais pode-se destacar os da dignidade humana e defesa do consumidor.

$\mathrm{O}$ caput do referido dispositivo menciona que a ordem econômica tem por fim assegurar a todos existência digna. Esse trecho deve ser lido em consonância com o inciso III, do artigo $1^{\circ}$, da Constituição, que institui como fundamento da Republica a dignidade da pessoa humana.

A dignidade da pessoa humana surge então mais do que como princípio, mas como fundamento $\mathrm{e}$ finalidade de toda a atividade econômica, como causa e objetivo. Assim também com a publicidade, que encontra seu fim também na promoção, proteção e desenvolvimento da dignidade humana.

No sistema constitucional brasileiro, dentro da noção de dignidade humana podemos compreender a proteção ao livre desenvolvimento da personalidade, direito fundamental expressamente garantido pela constituição alemã $\tilde{a}^{22}$. Se a todos se garante esse direito, mais ainda às crianças, pois é sabido que a infância é o período crucial no desenvolvimento da personalidade do indivíduo, estando pois muito mais suscetível e intelectual e psicologicamente desprotegido a todo estímulo externo, inclusive à publicidade.

Para Diógenes Faria de Carvalho 23 "as crianças constituem alvos fáceis para as mensagens publicitárias, já que possuem uma diminuta capacidade de seleção e contraargumentação, não compreendem os objetivos econômicos da publicidade, são incapazes até certa idade de diferenciar programas não

\footnotetext{
${ }^{22}$ Artigo 2 [Direitos de liberdade]

(1) Todos têm o direito ao livre desenvolvimento da sua personalidade, desde que não violem os direitos de outros e não atentem contra a ordem constitucional ou a lei moral.

23 CARVALHO, Diógenes Faria de. Revista do Consumidor. v. 94, p. 181, jul-ago, 2014.

24 SCHMITT, Cristiano Heineck. Consumidores hipervulneráveis: a proteção do idoso no mercado de consumo. São Paulo: Atlas, 2014, p. 229.

${ }^{25}$ A doutrina não apresenta uniformidade quanto à listagem exata dos princípios que regem a atividade publicitária no
}

comerciais e publicidade e, ainda, atribuem muita credibilidade à televisão".

A ordem econômica e, por consequência a publicidade, também está submetida ao princípio da defesa do consumidor. Essa última, por sua vez, é garantia constitucional prevista no rol do artigo $5^{\circ}$, gozando, pois, de prestígio diferenciado em nosso ordenamento. Dessa forma, a publicidade necessita de um regramento e limites específicos a fim de proteger o ente vulnerável da relação de consumo, que é o consumidor, e especialmente, nessa condição, as crianças.

A necessidade de proteção especial às crianças também encontra fundamento no princípio da proteção integral, previsto no artigo 227, da Constituição Federal e aplicável a todo ordenamento jurídico nacional. A criança, porque ainda em desenvolvimento, apresenta especial fragilidade diante da mensagem publicitária, podendo ser permanentemente afetada por estímulos de consumismo precoce, desencadeando problemas de ordem pessoal e até mesmo social ${ }^{24}$.

\section{PRINCÍPIOS QUE FUNDAMENTAM A PROIBIÇÃO DA PUBLICIDADE DIRIGIDA À CRIANÇA}

Além dos princípios constitucionais gerais, a atividade publicitária no Brasil está regulada por uma série de princípios específicos. ${ }^{25}$ Aqui podemos mencionar o ensinamento sempre pertinente de Antonio Herman de Vasconcellos e Benjamin, que esclarece que não se pode

Brasil. Bruno Miragem faz referência aos princípios da identificação, da veracidade e da vinculação. MIRAGEM, Bruno. Curso de Direito do Consumidor. 5. ed. São Paulo: Editora Revista dos Tribunais, 2014, p. 253. Antonio Herman Benjamim, por sua vez, acrescenta a esses os princípios da não abusividade, da inversão do ônus da prova, da transparência da informação, da correção do desvio publicitário e da lealdade publicitária. BENJAMIN, Antônio Herman V. et al. Manual de Direito do Consumidor. 3. ed. São Paulo: Editora Revista dos Tribunais, 2010, p. 234-236. 
confundir os princípios gerais da atividade publicitária com os princípios da proteção publicitária do consumidor. Segundo o autor, esses últimos pretendem ao sistema do Código de Proteção e Defesa do Consumidor, enquanto "aqueles, diversamente, encontram amparo no feixe de normas, de direito público e privado, que rege o fenômeno publicitário nas suas diversas facetas" $" 26$.

Acima tratamos, pois, dos princípios gerais, adiante trataremos dos princípios específicos da proteção do consumidor. Dentre aqueles que regem a publicidade abusiva, alguns se destacam especialmente na fundamentação da proibição da publicidade dirigida à criança.

\subsection{Princípio da identificação}

O princípio da identificação da mensagem publicitária decorre do disposto no art. 36 do Código de Defesa do Consumidor que assim dispõe: "A publicidade deve ser veiculada de tal forma que o consumidor, fácil e imediatamente, a identifique como tal". Dessa regra legal, depreende-se que a mensagem comercial deva ser de imediato identificada pelo destinatário, no mesmo instante de sua exposição e, ainda, ser de fácil entendimento, isto é, sem esforço ou conhecimento específico ou de graduação de intelectual. Tal princípio decorre diretamente da boa-fé objetiva, compreendidas pela eticidade, lealdade e transparência, valores estes que devem reger as relações de consumo.

No Código Brasileiro de Autoregulamentação Publicitária o princípio da identificação da mensagem publicitária também está presente no art. 28 que assim prevê: "O anúncio deve ser claramente distinguido como tal,

${ }^{26}$ BENJAMIN, Antônio Herman V., 2010. op. cit., p. 233 234.

27

CONSELHO

NACIONAL

DE AUTORREGULAMENTAÇÃO PUBLICITÁRIA. Código Brasileiro de Autorregulamentação publicitária. Disponível em: <http://www.conar.org.br/>. Acesso em: 26 jun. 2016. seja qual for a sua forma ou meio de veiculação. , 27

Nessa mesma linha, Lucia Ancona explica que "o princípio da identificação da mensagem publicitária decorre do próprio dever de transparência e lealdade nas relações de consumo, já que o ocultamento do caráter publicitário pode induzir o consumidor em erro quanto à natureza da mensagem, na hipótese, de fins comerciais, não meramente informativa e desinteressada". ${ }^{28}$

Consoante entendimento de Cláudia Lima Marques o princípio da identificação obrigatória da mensagem publicitária "serve, de um lado, para proibir a chamada publicidade subliminar, a qual atingiria somente o inconsciente do indivíduo e que, por seu grande perigoso potencial de sugestão, está proibida no mundo desde os anos setenta; de outro lado, o princípio afeta também a prática de merchandising". ${ }^{29}$

Em decorrência da aplicação da legislação consumerista, destaca-se o julgamento do Recurso Especial n ${ }^{\circ}$ 1.101.949/DF caracterizando violação ao princípio da não identificação da publicidade: "[...]1.5.1. O teor dos artigos $36 \mathrm{e}$ 37, do CDC, nítida a ilicitude da propaganda veiculada. A uma, porque feriu o princípio da identificação da publicidade. A duas, porque revelou-se enganosa, induzindo o consumidor a erro porquanto se adotasse a conduta indicada pela publicidade, independente das consequências, teria condições de obter sucesso em sua vida. [...] 1.5.3 Em razão da inexistência de uma mensagem clara, direta que pudesse conferir ao consumidor a sua identificação imediata (no momento da exposição) e fácil (sem esforço ou capacitação técnica), reputa-se que a publicidade ora em debate, de fato, malferiu a redação do art. 36, do CDC e, portanto, cabível e

${ }^{28}$ DIAS, 2013. op. cit., p. 65.

${ }^{29}$ MARQUES, Cláudia Lima. Contratos no Código de Defesa do Consumidor: o novo regime das relações contratuais. 4. ed. Ver. Atual e ampl. São Paulo: Editora Revista dos Tribunais, 2004. p. 659. 
devida a reparação dos danos morais coletivos.[... $]^{30}$

Quanto ao descumprimento do disposto no art. 36 do Código de Defesa do Consumidor, o parágrafo único 'b' do art. 19 do Dec. 2.181, de 20.03.1997, prevê a aplicação de multa ao fornecedor que "veicular publicidade de forma

${ }^{30}$ RECURSO ESPECIAL - AÇÃO CIVIL PÚBLICA -
DANO MORAL COLETIVO - DIVULGAÇÃO DE
PUBLICIDADE ILIICITA - INDENIZAÇÃO -
SENTENÇA QUE ACOLHEU O PEDIDO INICIAL DO
MPDFT FIXANDO A REPARAÇÃO EM R\$
14.000.000,00 (QUATORZE MILHÕES DE REAIS) E
DETERMINOU A A ELABORAÇÃO DE
CONTRAPROPAGANDA, SOB PENA DE MULTA
DIÁRIA - INCONFORMISMOS DAS RÉS -
APELAÇÃO PARCIALMENTE PROVIDA PARA
REDUZIR O QUANTUM INDENIZATÓRIO E
EXCLUIR DA CONDENAÇÃO OBRIGAÇÃO DE
FAZER CONTRAPROPAGANDA, BEM COMO A
MULTA MONITÓRIA PARA A HIPÓTESE DE
DESCUMPRIMENTO. IRRESIGNAÇÃO DAS RÉS -
OGILVY BRASIL COMUNICAÇÃO LTDA. E DA
SOUZA CRUZ S/A - E DO MINISTERIO PUUBLICO
DO DISTRITO FEDERAL E TERRITÓRIOS. 1. DO RECURSO ESPECIAL DA OGILVY BRASIL COMUNICAÇÃO LTDA.

(...)

1.4. Os fatos que ensejaram a presente demanda ocorreram anteriormente à edição e vigência da Lei $n^{\circ}$ $10.167 / 2000$ que proibiu, de forma definitiva, propaganda de cigarro por rádio e televisão.

Com efeito, quando da veiculação da propaganda vigorava a Lei $\mathrm{n}^{\circ}$ 9.294/96, cuja redação original restringia entre $21 \mathrm{~h} 00$ e $06 \mathrm{~h} 00$ a publicidade do produto. $\mathrm{O}$ texto legal prescrevia, ainda, que a publicidade deveria ser ajustada a princípios básicos, não podendo, portanto, ser dirigida a crianças ou adolescentes nem conter a informação ou sugestão de que o produto pudesse trazer bem-estar ou benefício à saúde dos seus consumidores. Isso consta dos incisos II e VI do $\S 1^{\circ}$, art. $3^{\circ}$ da referida lei.

1.5. O direito de informação está fundamentado em outros dois direitos, um de natureza fundamental, qual seja, a dignidade da pessoa humana, e outro, de cunho consumerista, que é o direito de escolha consciente. Dessa forma, a teor dos artigos $9^{\circ}$ e 31 do CDC, todo consumidor deve ser informado de forma "ostensiva e adequadamente a respeito da nocividade ou periculosidade do produto".

1.5.1. A teor dos artigos 36 e 37, do CDC, nítida a ilicitude da propaganda veiculada. A uma, porque feriu o princípio da identificação da publicidade. A duas, porque revelou-se enganosa, induzindo o consumidor a erro porquanto se adotasse a conduta indicada pela publicidade, independente das consequiências, teria condições de obter sucesso em sua vida. que o consumidor não possa, fácil e imediatamente, identifica-la como tal." Destacase o fato de que a sanção estabelecida no Decreto pode alcançar tanto a agência de publicidade quanto o veículo de comunicação que divulgou tal ato, conforme prevê o parágrafo único do art. $18^{31}$ do mesmo diploma legal.

1.5.2. Além disso, a modificação do entendimento lançado no v. acórdão recorrido, o qual concluiu, após realização de contundente laudo pericial, pela caracterização de publicidade enganosa e, por conseguinte, identificou a responsabilidade da ora recorrente pelos danos suportados pela coletividade, sem dúvida demandaria a exegese do acervo fático-probatório dos autos, o que é vedado pelas Súmulas 5 e 7 do STJ.

1.5.3. Em razão da inexistência de uma mensagem clara, direta que pudesse conferir ao consumidor a sua identificação imediata (no momento da exposição) e fácil (sem esforço ou capacitação técnica), reputa-se que a publicidade ora em debate, de fato, malferiu a redação do art 36, do CDC e, portanto, cabível e devida a reparação dos danos morais coletivos.

(...)

(REsp 1101949/DF, Rel. Ministro MARCO BUZZI, QUARTA TURMA, julgado em 10/05/2016, DJe 30/05/2016)"

${ }^{31}$ Art. 18. A inobservância das normas contidas na Lei $n^{\circ}$ 8.078, de 1990, e das demais normas de defesa do consumidor constituirá prática infrativa e sujeitará o fornecedor às seguintes penalidades, que poderão ser aplicadas isolada ou cumulativamente, inclusive de forma cautelar, antecedente ou incidente no processo administrativo, sem prejuízo das de natureza cível, penal e das definidas em normas específicas:

I - multa;

II - apreensão do produto;

Ill - inutilização do produto;

IV - cassação do registro do produto junto ao órgão competente;

V - proibição de fabricação do produto;

VI - suspensão de fornecimento de produtos ou serviços;

VII - suspensão temporária de atividade;

VIII - revogação de concessão ou permissão de uso;

IX - cassação de licença do estabelecimento ou de atividade; $X$ - interdição, total ou parcial, de estabelecimento, de obra ou de atividade;

XI - intervenção administrativa;

XII - imposição de contrapropaganda.

$\S 1^{\circ}$ Responderá pela prática infrativa, sujeitando-se às sanções administrativas previstas neste Decreto, quem por ação ou omissão lhe der causa, concorrer para sua prática ou dela se beneficiar.

$\S 2^{\circ}$ As penalidades previstas neste artigo serão aplicadas pelos órgãos oficiais integrantes do SNDC, sem prejuízo das atribuições do órgão normativo ou regulador da atividade, na forma da legislação vigente. 
Ora, é fato que a criança, pela sua reduzida capacidade cognitiva e, especialmente, pela sua imaturidade em distinguir o real do imaginário, não tem condições de constatar quando está diante de uma mensagem publicitária. ${ }^{32}$

Atualmente, a violação ao princípio da identificação publicitária tem sido maciça no ambiente virtual, especialmente nas mídias móveis, tais como tabletes e smartphones. "Nos ambientes de mobilidade, o assédio das crianças sem a mediação do adulto é tão mais facilitado quanto difícil se torna para as crianças identificar os apelos do marketing. O leque de formatos possíveis de inserção comercial na web é infinito: banners, patrocínios, email, pop up, entre muitas outas novidades, o que implica riscos que passam pela compra inadvertida de produtos até a exposição de dados privados ou sigilosos." 33

O caso dos youtubers mirins também é um bom exemplo relacionado ao princípio da identificação. Trata-se aqui de pequenas celebridades que possuem canais no Youtube e perfis em diferentes redes sociais "e que chegam a mais de 240 mil assinantes ou seguidores e impressionantes 91.974 .702 visualizações de seus vídeos. Essas crianças recebem presentes e são cooptadas pelas marcas para trabalhar para elas, de forma velada, vendendo produtos em seus

\footnotetext{
$\S 3^{\circ}$ As penalidades previstas nos incisos III a XI deste artigo sujeitam-se a posterior confirmação pelo órgão normativo ou regulador da atividade, nos limites de sua competência.

32 Sobre as condições psicológicas da criança frente à publicidade dirigida a esse público, esclarece Yves De La Taille, que "i. A publicidade tem maior possibilidade de induzir ao erro as crianças até os 12 anos, quando não possuem todas as ferramentas necessárias para compreender o real; ii. As crianças não têm a mesma capacidade de resistência mental e de compreensão da realidade que um adulto; e iii. As crianças não estão com condições de enfrentar com igualdade de força a pressão exercida pela publicidade no que se refere à questão do consumo". In: $A$ publicidade dirigida ao público infantil: considerações psicológicas. Disponível em: <http://www.crprj.org.br/noticias/2008/0305-publicidadedirigida-ao-publico-infantil.html>. Acesso em: 22 jun. 2016.
}

canais e criando fidelidade e adesão entre seus pares". 34

A confusão entre publicidade e lazer na mente infantil é mencionada por Guilherme Magalhaes Martins, que menciona "o uso dos chamados recursos "under the radar", como o merchandising em filmes, livros e na televisão", cujos "riscos são potencializados pelo uso crescente da internet e das redes sociais, onde as crianças e adolescentes são submetidas não somente ao assédio da publicidade, que hoje se volta, sobretudo, para a telefonia celular. Tais fatores, associados a situações cotidianas como o pagamento a DJs pela inclusão de temas sonoros que identificam produtos em programações musicais esvazia cada vez mais a diferença entre publicidade e entretenimento." 35

\subsection{Princípio da não abusividade}

O princípio da não abusividade da mensagem publicitária encontra-se disposto no próprio conceito de publicidade abusiva, previsto no $\S 2^{\circ}$ do art. 37 do Código de Defesa do Consumidor $^{36}$, segundo o qual:

[...] é abusiva, dentre outras, a publicidade discriminatória de qualquer natureza, a que incite à violência, explore o medo ou a superstição, se aproveite da deficiência de julgamento e experiência

${ }^{33}$ FONTENELLE, Lais. A onipresente publicidade infantil na internet. Disponível em: $<$ http://outraspalavras.net/brasil/a-onipresente-publicidadeinfantil-na-internet/>. Acesso em: 19 set. 2016.

${ }^{34}$ Idem

35 MARTINS, Guilherme Magalhaes. A regulação da publicidade infantil no Brasil: A proteção do consumidor e da infância. Revista do Direito do Consumidor, v. 102, p.299-300, nov-dez, 2015.

${ }^{36}$ Art. 37. É proibida toda publicidade enganosa ou abusiva. $\S 2{ }^{\circ}$ É abusiva, dentre outras a publicidade discriminatória de qualquer natureza, a que incite à violência, explore o medo ou a superstição, se aproveite da deficiência de julgamento e experiência da criança, desrespeita valores ambientais, ou que seja capaz de induzir o consumidor a se comportar de forma prejudicial ou perigosa à sua saúde ou segurança. 
da criança, desrespeite valores ambientais, ou que seja capaz de induzir o consumidor a se comportar de forma prejudicial ou perigosa à sua saúde ou segurança.

Da leitura do dispositivo, conclui-se que se trata de rol meramente exemplificativo, uma vez que o legislador utiliza a expressão "dentre outras", caracterizando um conceito jurídico aberto.

Mas ainda que assim não fosse, a regra é taxativa ao caracterizar como abusiva a publicidade que se aproveita da deficiência de julgamento e experiência da criança. Dessa forma, estando a criança ainda em fase de desenvolvimento psíquico, cognitivo e emocional, qualquer mensagem de consumo a ela dirigida, independentemente de seu conteúdo, fere o princípio da não-abusividade.

Na lição de Clóvis de Barros Filho:

[...] para poder decidir, uma criança ou um préadolescente precisa estar em posse das faculdades racionais, o que não ocorre. A psicanálise de Freud e a teoria do desenvolvimento cognitivo de Jean Piaget ([1955] 1976) provaram que nos primeiros anos de vida os humanos são regidos pelo inconsciente, pelas fantasias infantis, estando limitados no plano cognitivo ao período sensório-motor (zero a dois anos) rumo ao operatório concreto (sete a doze anos). Logo, crianças e pré-adolescentes não têm plena posse das faculdades racionais. Não faz sentido persuadi-los com informações, pois não são capazes de escolher o que é melhor para si. ${ }^{37}$

Dessa forma, a abusividade da publicidade dirigida à criança produz efeitos adversos no que respeita a formação da sua personalidade, caráter, construção de valores éticos, sociais, culturais e morais. Nesse sentido, Isabella Vieira Machado Henriques, aduz que "publicidades geram, no final das contas, tristezas, decepções e frustrações por motivos fúteis e banais - tais como o de não

\footnotetext{
${ }^{37}$ FILHO, Clovis de Barros. A defesa liberal da restrição publicitária ao público infantil: Ética e educação. In: FONTENELLE, Lais (org.). Criança e consumo: 10 anos de transformação. 1. ed., São Paulo: Instituto Alana, 2016. p. 149-150.
}

possuir determinado produto ou o de não usufruir determinado serviço que nunca seriam dessa forma vivenciados pela criança. Ou, quanto pior, geram inveja, ganância, gula e um consumismo despropositado." Prossegue ela:

[...] isso sem falar nos perigos que podem ser causados à saúde e integridade física da criança quanto a influência da publicidade em sua psique for levada ao extremo, [...]. Isso pode ocorrer nos casos em que a publicidade influencie a criança a ter alguma atitude que seja perigosa e traga riscos a sua própria saúde, como, por exemplo, acreditar que poderá voar com a capa do Superman, pulando da janela de seu apartamento de um alto edifício ou então cobrir a cabeça com um saco plástico para brincar de modelo futurista. ${ }^{38}$

Na lição de Lucia Ancona, a norma legal que define a abusividade da publicidade é de:

[...] conteúdo vasto e flexível, pode-se afirmar que o $\$ 2^{\circ}$ do art. 37 do Código de Defesa do Consumidor institui para as relações de consumo o princípio geral da não abusividade ao vedar qualquer forma de publicidade que atente contra os valores éticos e morais da sociedade, em desrespeito ao consumidor, ou que possa induzi-lo a se comportar de forma prejudicial a sua saúde e segurança.

Refere ainda, que a referida disposição legal combinada com os incisos I a VI do art. $6^{\circ}$ do Código de Defesa do Consumidor, que trata dos direitos básicos, têm por finalidade "assegurar a sua incolumidade física e psíquica e preveni-lo contra a veiculação de publicidade que de algum modo possa levá-lo a se comportar de forma perigosa, colocando em risco a sua saúde ou segurança". 39

Cabe ressaltar, que há também previsão expressa no Código de Ética do CONAR, sobre proibição de veiculação de publicidade que transgrida valores morais e a dignidade da pessoa humana. Mais especificamente sobre a

\footnotetext{
${ }^{38}$ HENRIQUES, Isabela Vieira Machado. op. cit., p.188-
} 189.

${ }^{39}$ DIAS, 2013. op. cit. p. 86-87. 
publicidade dirigida à criança, destaca-se o art. 23 do referido Código que prevê expressamente que “os anúncios devem ser realizados de forma a não abusar da confiança do consumidor, não explorar sua falta de experiência ou de conhecimento e não se beneficiar de sua credulidade".

A noção de abusividade pode também ser extraída a partir dos valores implícitos na Lei $\mathrm{n}^{\circ} 13.257$, de 08 de março de 2016, que estabelece princípios e diretrizes para implementação das políticas públicas destinadas a primeira infância. Consta expressamente em seu art. $5^{\circ}$ a previsão da proteção da criança "contra toda forma de violência e de pressão consumista" e para que "evitem a exposição precoce à comunicação mercadológica." Tal regramento, em uma interpretação sistemática e até mesmo por uma questão de responsabilidade social, sobrepõe-se aos interesses comerciais da atividade publicitária especificamente quanto ao público infantil.

\subsection{Princípio da (hiper) vulnerabilidade ou} vulnerabilidade agravada do público infantil

O Código de Defesa do Consumidor considera todo consumidor a parte vulnerável na relação de consumo. $\mathrm{O}$ princípio da vulnerabilidade é um princípio estruturante e informador da Política Nacional de Relações de Consumo. Por força do disposto no inciso I do art. 4. ${ }^{\mathrm{o} 0}$ do Código de Defesa do Consumidor, todo consumidor é reconhecidamente vulnerável no mercado de consumo por sua condição intrínseca: a de ser a parte mais fraca na relação contratual. Mais ainda, a categoria de consumidores que apresentam condições específicas, como é o caso das crianças, idosos e portadores de necessidades

\footnotetext{
40 “Art. 4 A Política Nacional das Relações de Consumo tem por objetivo o atendimento das necessidades dos consumidores, $[\ldots]$ atendidos os seguintes princípios:

I - reconhecimento da vulnerabilidade do consumidor no mercado de consumo; " (Redação dada pela Lei no 9.008, de 21.3.1995) (BRASIL, Código de Defesa do Consumidor. Disponível
}

especiais, são classificados por doutrinadores contemporâneos como consumidores hipervulneráveis ou com vulnerabilidade agravada.

$\mathrm{Na}$ visão de Cláudia Lima Marques, a hipervulnerabilidade:

\begin{abstract}
[...] seria a situação social fática e objetiva de agravamento da vulnerabilidade da pessoa física consumidora, por circunstâncias pessoais aparentes ou conhecidas do fornecedor, como sua idade reduzida (assim o caso da comida para bebês ou da publicidade para crianças) [...]. Em outras palavras, enquanto a vulnerabilidade "geral" do art. $4^{\circ}$, I do CDC se presume e é inerente a todos os consumidores, a hipervulnerabilidade seria inerente e "especial" à situação pessoal de um consumidor, [...]. Concorda-se com a doutrina quando defende que a hiper (ou alta) vulnerabilidade tem garantia constitucional, e atinge, assim, especialmente, os vulneráveis mencionados na Constituição, os portadores de deficiência, os idosos, as crianças e os adolescentes. $^{41}$
\end{abstract}

A vulnerabilidade possui um conceito jurídico classificado como de direito material que evidencia uma situação de desequilíbrio vivenciada pelo agente econômico - o consumidor - frente ao fornecedor de produtos ou serviços. Essa fragilidade é agravada, em razão das próprias características intrínsecas ao público infantil.

Para Lucia Ancona, os infantes:

[...] merecem atenção especial do legislador, pois, embora não sejam parte da relação de consumo, são fortemente influenciadas pelas mensagens publicitárias que podem dar causa a essa relação por meio de seus pais ou terceiros. Trata-se, na verdade, do público-alvo mais vulnerável e suscetível aos apelos publicitários, notadamente porque, a depender da sua faixa etária, a criança sequer tem condições de distinguir o caráter publicitário da

http://www.planalto.gov.br/ccivil_03/leis/L8078.htm. Acesso em: 26 jun. 2016)

41 MARQUES, Cláudia Lima. Diálogo das Fontes: do conflito à coordenação de normas do direito brasileiro. 1 . ed. São Paulo: Editora Revista dos Tribunais, 2012. p. 4144. 
mensagem a que está submetida e entender os seus efeitos persuasivos ${ }^{42}$.

Bruno Miragem disserta com muita propriedade que a vulnerabilidade da criança consumidora "é mais intensa do que a do consumidor médio, conforme hoje é admitido, de modo a dizer-se que conta com espécie de vulnerabilidade agravada

ou hipervulnerabilidade" ${ }^{, 43}$.

Sobre hipervulnerabilidade da criança frente à publicidade, destaca Cristiano Heineck Schimitt, in verbis:

\begin{abstract}
Assevera-se que as crianças não têm condições de compreensão e entendimento do conteúdo implícito presente na informação publicitária, muito menos, seu caráter persuasivo, incentivador do consumo. Aliás, esses indivíduos sequer têm o entendimento necessário para observar que dada comunicação é publicidade. Evidentemente, um adulto possui muito mais força de resistência mental e de apreensão da realidade do que uma criança, podendo enfrentar a pressão exercida pela publicidade. A ausência dessa característica na criança, que não tem aptidão para analisar criticamente uma dada informação, deflagra um grau maior de vulnerabilidade, de forma que ela se enquadra também na concepção de hipervulnerabilidade, de forma que ela se enquadra também na concepção de hipervulnerável. ${ }^{44}$
\end{abstract}

O poder exercido pela criança nas decisões de consumo da família contrasta com a vulnerabilidade que apresenta frente à relação formada com fornecedores de produtos ou serviços. Os infantes encontram-se "em estágio de vida em que não apenas permite que se deixem convencer com maior facilidade, em razão de uma formação intelectual incompleta, como também não possuem, em geral, o controle sobre aspectos práticos da contratação, como os valores financeiros envolvidos, os riscos e benefícios do negócio. Daí resulta que estejam em posição de maior debilidade com relação à vulnerabilidade que se reconhece a um consumidor standart. Esta vulnerabilidade agravada do consumidor-criança é reconhecida no âmbito da publicidade" ${ }^{45}$.

Constata-se, pois, que a consumidoracriança carece de amadurecimento cognitivo suficiente frente aos verdadeiros ataques efetivados pela publicidade abusiva, razão pela qual encontra-se em situação de especial vulnerabilidade.

\section{CONSIDERÇÕES FINAIS}

Diante do exposto pode-se então considerar que a atividade publicitária é atividade econômica amparada pelo regime constitucional e legal da ordem econômica e que nessa condição não goza da mesma proteção aplicável à garantia da liberdade de expressão.

Nesse contexto, seu exercício está condicionado à observâncias dos princípios constitucionais da dignidade da pessoa humana, da defesa do consumidor e da proteação integral da criança.

Quando dirigida à criança, a publicidade deve ser considerada per se abusiva, independente do seu conteúdo, pois a utilização de crianças como destinatários da mensagem comercial viola princípios da proteção publicitária do consumidor, especialmente os da identificação e da não abusividade da publicidade, bem como o princípio da hipervulnerabilidade desse sujeito especial de direitos no mercado de consumo.

\section{REFERÊNCIAS}

\footnotetext{
${ }^{42}$ DIAS, Lucia Ancona Lopez de Magalhaes. Publicidade e hipervulneráveis: limitar, proibir ou regular? Revista de Direito do Consumidor. v. 99, p.285-305, mai-jun, 2015.

${ }^{43}$ MIRAGEM, Bruno. op. cit., p. 467.
}

44 SCHMITT, Cristiano Heineck. Consumidores hipervulneráveis: a proteção do idoso no mercado de consumo. São Paulo: Atlas, 2014, p. 229.

${ }^{45}$ DIAS, 2013, op. cit., p. 86-87 
BENJAMIN, Antônio Herman V. et al. Manual de Direito do Consumidor. 3. ed. São Paulo: Editora Revista dos Tribunais, 2010.

BRASIL, Código de Defesa do Consumidor. Disponível em: <http://www.planalto.gov.br/ccivil_03/leis/L8078.htm>. Acesso em: 26 jun. 2016

CARVALHO, Diógenes Faria de. Revista do Consumidor. v. 94, p. 181, jul-ago, 2014.

CONSELHO NACIONAL DE AUTORREGULAMENTAÇÃO PUBLICITÁRIA . Código Brasileiro de Autorregulamentação publicitária. Disponível em: <http://www.conar.org.br/>. Acesso em: 26 jun. 2016.

CRPRJ. A publicidade dirigida ao público infantil: considerações psicológicas. Disponível em:<http://www.crprj.org.br/noticias/2008/0305-publicidade-dirigida-ao-publico-infantil.html>.

Acesso em: 22 jun. 2016.

DENARI, Zelmo. A comunicação social perante do Código de Defesa do Consumidor. Revista de Direito do Consumidor. São Paulo, n. 4, p. 135.

DIAS, Lucia Ancona Lopez de Magalhaes. Publicidade e direito. 2. ed. São Paulo: Revista dos Tribunais, 2013.

DIAS, Lucia Ancona Lopez de Magalhaes. Publicidade e hipervulneráveis: limitar, proibir ou regular?. Revista de Direito do Consumidor. v. 99, p.288, mai-jun, 2015. DTR\2015\10681

FILHO, Clovis de Barros. A defesa liberal da restrição publicitária ao público infantil: Ética e educação. In: FONTENELLE, Lais (org.). Criança e consumo: 10 anos de transformação. 1. ed., São Paulo: Instituto Alana, 2016.

FONTENELLE, Lais. A onipresente publicidade infantil na internet. Disponível em: <http://outraspalavras.net/brasil/a-onipresente-publicidade-infantil-na-internet/>. Acesso em: 19 set. 2016.

JUNIOR, Nelson Nery. Limites para publicidade infantil: Direito fundamental à comunicação e liberdade de expressão da iniciativa privada. Soluções Práticas de Direito. Revista dos Tribunais. v. 1, 2014.

MARQUES, Claudia Lima. Contratos no Código de Defesa do Consumidor: o novo regime das relações contratuais. 7. ed. São Paulo: Revista dos Tribunais, 2014.

MARQUES, Cláudia Lima. Diálogo das Fontes: do conflito à coordenação de normas do direito brasileiro. 1. ed. São Paulo: Editora Revista dos Tribunais, 2012.

MARTINO, Luiz Cláudio. PAVARINO, Rosana Nantes. História e teoria da publicidade: origem e autonomia. Colección Académica de Ciencias Sociales da Universida Pontificia Bolivariana. Seccional Palmira. v. 2., n. 1. 2015.

MARTINS, Guilherme Magalhaes. A regulação da publicidade infantil no Brasil: A proteção do consumidor e da infância. Revista do Direito do Consumidor, v. 102, p. 299-300, nov-dez, 2015. 
MELNIK, Luis. La Publicidad: princípios, médio y fines. Buenos Aires: Editorial Sudamericana, 1994.

MIRAGEM, Bruno. Curso de Direito do Consumidor. 5. ed. São Paulo: Editora Revista dos Tribunais, 2014.

. Proteção da criança e do adolescente consumidores. Possibilidade de explicitação de critérios de interpretação do conceito legal de publicidade abusiva e prática abusiva em razão de ofensa a direitos da criança e do adolescente por resolução do Conselho Nacional da Criança e do Adolescente - CONANDA. PARECER. Revista de Direito do Consumidor. v. 95, p. 460, set-out, 2014.

PASQUALOTTO, Adalberto (Org.). Publicidade de Tabaco: frente e verso da liberdade de expressão comercial. São Paulo: Atlas, 2015, Prefácio, p. XIII.

$\overline{\text { jun.,2012. }}$

Publicidade de tabaco e liberdade de expressão. Revista Direito do Consumidor. v. 82, abr.-

RIMOLI, Ariane Porto Costa. O mundo da comunicação e o mundo da criança. Comunicação \& Educação. São Paulo, v. 21, n. 1, p. 51-59, may 2016. ISSN 2316-9125. Disponível em: <http://www.revistas.usp.br/comueduc/article/view/96724>. Acesso em: 03 jul. 2016. doi:http://dx.doi.org/10.11606/issn.2316-9125.v21i1p51-59

SCHMITT, Cristiano Heineck. Consumidores hipervulneráveis: a proteção do idoso no mercado de consumo. São Paulo: Atlas, 2014.

SILVA, Virgílio Afonso da. A constitucionalidade da restrição da publicidade de alimentos e de bebidas não alcóolicas voltada ao público infantil (Parecer). São Paulo: Instituto Alana, 2012. Disponível em: <http://criancaeconsumo.org.br/wpcontent/uploads/2014/02/Parecer_Virgilio_Afonso_6_7_12.pdf>. Acesso em: 26 jun. 2016.

Recebido em: 29/09/2016 Aceito em: 07/06/2017 
